\title{
QUALITY IMPROVEMENT DESIGN AT ISLAMIC SCHOOLS POST-COVID-19 PANDEMIC IN ELEMENTARY SCHOOL AND INTEGRATED EARLY CHILDHOOD EDUCATION OF SALEH CHILDREN, MALANG CITY
}

\author{
Muhammad Fahmi Hidayatullah \\ Universitas Islam Malang, Jawa Timur, Indonesia \\ m.fahmihidayatullah@unisma.ac.id
}

\begin{abstract}
The combination of integrated educational design by integrating general science and religion and the religious character-building education has made the public entrust their sons and daughters to study at the institution. However, the problem is that quality is always a problem, even though the expectation of quality education is a requirement. The Anak Saleh Educational Foundation in Malang City is a consistent institution and committed to quality improvement. Researchers collect data using a descriptive qualitative approach and case study research type with a multi-cases design. Data collection techniques using in-depth interviews, participatory observation, and documentation. The data analysis technique used cross-case data analysis. The results showed connectivity between input, process, and output in improving the quality of Islamic education institutions based on the institution's philosophy, namely Panca Character.
\end{abstract}

Keywords: Design, Quality Improvement, Islamic Schools

\section{INTRODUCTION}

The phenomenon of schools closing during the pandemic is very alarming, considering the number is quite significant. Citing data from the Ministry of Education and Culture in 2020, 646,200 schools were closed due to the COVID-19 outbreak. While globally, 1.3 billion people have closed due to the coronavirus outbreak. So that education with virtual learning from home design involves 68.8 million students and 4.2 million teachers and lecturers (Al Faqir, 2020). This fact is a challenge for educational institutions in maintaining the quality of post-pandemic institutions. 
Hidayatullah, M. F. (2021). QUALITY IMPROVEMENT DESIGN AT ISLAMIC SCHOOLS POST-COVID-19 PANDEMIC IN ELEMENTARY SCHOOL AND INTEGRATED EARLY CHILDHOOD EDUCATION OF SALEH CHILDREN, MALANG CITY. Jurnal Tatsqif, 19 (1), 81-97. https://doi.org/10.20414/jtq.v19i1.3570

In addition, the COVID-19 pandemic threatens private schools potentially to go out of business due to institutional operational problems, especially related to financial management (Rochim, 2020). As occurred in the Regency and City of Mojokerto, one of the Vocational High Schools (SMK) decided to stop the institution's operations or close due to a shortage of students since up coming the 2019/2020 pandemic as a result of the zoning system, and it is getting heavier with the problems of the COVID-19 pandemic for the academic year 2020/2021 (Supriyatno, 2020).

Various problems amid a pandemic require institutions to continuously improve the quality of each component as set out in the National Education Standards. The pandemic as a global problem impacts the weakening of the country's economy (Rizescu, Alexandru; Tileag, 2017). When the economic aspect is disrupted, it also has an impact on the quality of education. One of the challenges in the globalization era and pandemics is the quality of output/outcomes (Rusmini, 2015). It means that the quality of education services and implementation are the primary solutions to address, add up the adequate infrastructure, quality teaching staff, laboratories, and other facilities in delivering quality education. According to the results of research by Ahmad Arifi, reforms carried out by Madrasas can create the ideal education and its quality (Arifi, 2008).

Quality is a primary requirement and a concrete step for postpandemic education so that institutions can survive and move quickly to rise up while maintaining the quality of their human resources. However, if the institutions' facilities and infrastructure are complete but the human resources are weak, the institution will not progress like a country with abundant natural resources but is weak in human resources (Rahmawati, 2012). Quality education is a source for producing future generations to advance science and technology (Mulyadi, 2007). In the design of business schools, efforts to make schools as institutions trusted 
by the community (with integrity) and graduates are widespread by providing many benefits, and there is a vital need that needs to be considered, namely technology as a need for globalization that makes institutions useful in a sustainable manner (Arevalo et al., 2020).

Improving the quality of education from time to time is always supported by the Minister of National Education, one of which is through the movement to improve the quality of national education on May 2, 2002, by Abdul Malik Fajar (Islam, 2013). The idea is a movement to build public awareness to generate qualified education as the essence of national education goals, namely facing globalization, it is necessary to improve education at all levels without exception by preparing creative, innovative generations and having strong sensitivity to the environment and circumstances (Hermawan et al., 2020).

Apart from this, the digital community is very active and responsive to the educational institutions of their children. As information obtained regarding the Ministry of National Education (Kemendikbud), there are concerns that parents and children will not get the best education (Seftiawan, 2019). Because the implementation of the zoning system basically narrows students to take tests at favorite educational institutions outside the area where they live. On the other hand, the zone system answers the fifth precept of Pancasila, namely social justice for all Indonesian people.

Therefore, as an educated nation, its citizen obliges to assist the government in responding to problems in society regarding the implementation of education policies. One of them is through quality private educational institutions. More private educational institutions in Indonesia than public educational institutions start from basic education to higher education. For example, the total schools in Indonesia from Elementary to Advanced levels, the comparison in 2017/2018 was 
Hidayatullah, M. F. (2021). QUALITY IMPROVEMENT DESIGN AT ISLAMIC SCHOOLS POST-COVID-19 PANDEMIC IN ELEMENTARY SCHOOL AND INTEGRATED EARLY CHILDHOOD EDUCATION OF SALEH CHILDREN, MALANG CITY. Jurnal Tatsqif, 19 (1), 81-97. https://doi.org/10.20414/jtq.v19i1.3570

307,655 schools with a composition of 169,378 public and 138,277 private schools (Kemendikbud, 2018).

The number of private schools in Indonesia is almost equal to the number of public schools, not to mention the number of private madrasah and Islamic boarding schools in Indonesia, which, in the end, when added up, private educational institutions outnumber public educational institutions. The fact means that private educational institutions make a significant contribution to the intellectual life of the Indonesian nation as in the history before Indonesia's independence, Pesantren contributed to providing education to the people of the Archipelago, including taking over the Dutch government schools, which later became state schools as they are today. Unfortunately, in terms of quality, especially Islamic educational institutions, the development is considered less significant as research by Ahmad Zaini Aziz, due to three things, namely the process of being ignored, centralized, and the collapse of harmonization of institutions with society (Aziz, 2015).

The Anak Saleh Education Foundation of Malang City is an Islamic educational institution in Malang City where its presence aims to present quality Islamic education from early childhood to sustainable levels (Administrator, 2020b). Based on the results of the researcher's observations, that the Anak Saleh Foundation has a characteristic to establish quality education, namely instilling the values of Five Characters in students, including personal, social, national, intellectual, and natural piety (Observasi, 2020a). Meanwhile, there are two educational institutions within the Foundation, namely the Anak Saleh Integrated Early Childhood Education (ECE) and Elementary School (ES).

One of the backgrounds for establishing the Anak Saleh Integrated ECE is to build quality and pious Muslim and Muslim children by providing them with the basics of faith, morals, knowledge, and skills (Administrator, 2020c). Meanwhile, regarding the establishment of the 
Anak Saleh Elementary School, there are three reasons behind it, namely the public high demand for primary Islamic education in Malang City, the limited capacity for quality primary education, and requests from parents/guardians of students through submitting proposals to the Foundation (Administrator, 2020a). Thus, these two institutions cannot be doubted in terms of improving the institution's quality, so that researchers are interested in exploring through research conducted related to the design of improving the quality of the institution.

\section{METHODE}

In research at Anak Saleh Integrated Early Childhood Education (ECE) and Elementary School (ES) Malang City, the approach used by the researcher was descriptive qualitative. This approach is in line with the views of Bogdan and Taylor through qualitative meaning as research by describing written and unwritten data based on extracting data from the results of participatory observations, in-depth interviews, and documentation (Bakri, 2013). The data is described naturally based on the place under study. The goal is to obtain data and meaning in narrative form.

Meanwhile, the type of research is a case study with a multi-case development design in which there is more than one locus (research place). This research type describes events that have occurred to the nature or character of an event (Santoso, 2005). The research locus is in the Anak Saleh Integrated ECE and ES, Malang City.

While the data collection techniques in this study, researchers used research triangulation at the Anak Saleh Foundation, Malang City, including in-depth interviews, involvement in observation, written documentation (Sugiono, 2016). Meanwhile, in the qualitative data analysis technique at the Anak Saleh Integrated Integrated ECE and ES in Malang City, the researchers used interactive data analysis (Miles, M.B, 
Huberman, A.M, dan Saldana, 2014) and cross-case data analysis, in which the researchers compared the Anak Saleh Integrated ECE and ES. And then, the researchers made a proposition and produced substantive and formal findings.

\section{FINDING AND DISCUSSION}

Quality is a requirement in every institution, amid the rapid development of science and technology as its existence in the community. People need educational institutions that are outstanding or are deemed a high value or quality. Efforts to make continuous improvements can be referred to as quality (Biadacz, 2021). Given that science and technology have become an inseparable unit, so that people flock to high-value educational institutions according to their needs.

The current condition has changed many people's paradigm of thinking. Quality is a priority for both services and goods. Services as processes carried out by humans, and the final results impacted themselves and the surrounding people and education. Quality institutions are portraits or overall characteristics of the educational process that meet the needs and provide satisfaction to students and parents (Rohiat, 2010). The process of satisfying customers (students and people who know) is related to quality human resources and school facilities with complete infrastructure and facilities for students (Engkoswara, 2012).

The success of educational institutions cannot be separated from their established quality. So the quality aspect needs to be considered. Quality in the context of education consists of inputs, processes, and outputs (Rohiat, 2010: 52). The three quality components are related to each other, which also have components, such as input (resources, software, expectations), process (decision making, institutional 
Hidayatullah, M. F. (2021). QUALITY IMPROVEMENT DESIGN AT ISLAMIC SCHOOLS POST-COVID-19 PANDEMIC IN ELEMENTARY SCHOOL AND INTEGRATED EARLY CHILDHOOD EDUCATION OF SALEH CHILDREN, MALANG CITY. Jurnal Tatsqif, 19 (1), 81-97. https://doi.org/10.20414/jtq.v19i1.3570

management, program management, learning process, evaluation monitoring), and output (academic). and non-academic) (Rohiat, 2010).

In line with the three quality components above, the steps of Anak Saleh Foundation for the Early Childhood Education (ECE) and Elementary School (ES) in improving quality include input (Quality Commitment, Institutional Philosophy), process (innovation of academic/non-academic activities and SWOT analysis), output (academic achievement) and non-academic. The explanation is as follows:

\section{- Input (Quality Commitment, Institutional Philosophy)}

Input is the first step in carrying out a process. It contains positive energy that drives system performance. Educational inputs (Mulyasa, 2014) include students, personnel, facilities, costs, curriculum, planning and evaluation, school-community relations, and an adequate school climate. Input has a very vital position in the institutional system. Its position as the principal capital of a system significantly influences the process and results. So to measure the effectiveness of a process, appropriate inputs and outputs are needed (Biadacz, 2021).

The input for the Anak Saleh Integrated ECE is reflected through the commitment to quality in the vision of the institution that wants to create quality, creative, fun, and Islamic education. The word quality is one indicator of quality. Furthermore, the quality is the commitment of the institution, which is written in its vision. Furthermore, written commitment will be biased if it is not kept up with a sense of belonging as a form of high commitment to improving the institution's quality by producing many achievements for students.

Meanwhile, the Anak Saleh Elementary School (ES) has a quality commitment built by the institution as the first step in its development. It is done by Anak Saleh ES, which continuously maintains and develops quality as stated in the Anak Saleh ES's mission, namely providing qualified Islamic primary education based on Islamic values. 
Hidayatullah, M. F. (2021). QUALITY IMPROVEMENT DESIGN AT ISLAMIC SCHOOLS POST-COVID-19 PANDEMIC IN ELEMENTARY SCHOOL AND INTEGRATED EARLY CHILDHOOD EDUCATION OF SALEH CHILDREN, MALANG CITY. Jurnal Tatsqif, 19 (1), 81-97. https://doi.org/10.20414/jtq.v19i1.3570

Furthermore, the second input is through the philosophy of the institution. As the following interview results:

The hallmark of the Anak Saleh school is that we have Five Characters of Pious Children, namely Personal Piety, Social Piety, Intellectual Piety, National Piety, and Natural Piety. We include these characteristics into the curriculum and are implemented in everyday life while children are in school or at home (our specialty has led us to become the 1st place winner at the East Java Level in the 2010 East Java Character School Widyapakarti Competition). Because we are in one organization, our philosophy is the same only in its application, judging from the child's chronological age; the older the age, the more structured and scholastic the application is. For example, in family planning, physical, motor, and social development is more developed. In kindergarten, development is cognitive and socio-spiritual; in elementary school, it is more for cognitive, psychomotor, affective, and spiritual strengthening (Wawancara, 2020a).

Based on the interview above, it can be seen that the existence of Islamic values is the basic foundation for the development of the two institutions, namely Anak Saleh Early Childhood Education (ECE) and Elementary School (ES). Islamic values are translated in terms of Panca's Character and become the hallmark of the character of the Anak Saleh Foundation students. The five characters include personal piety, social piety, intellectual piety, national piety, and naturalness. However, the difference is only at the level of philosophical implementation. If the Playgroup develops physical-motor and social, while in kindergarten it develops cognitive and socio-spiritual, and Elementary School develops cognitive, psychomotor, affective, and spiritual.

\section{- Process (Innovation for Academic/Non-Academic Activities)}

The definition of a process is an activity or event that occurs by planning or occurs naturally (Mulyasa, 2014). Important messages can be conveyed to students when educational actors can design creatively and interactively. The creative design of an idea implemented into reality is an innovative stage as Freedman (1998) argues that innovation is a process of starting or increasing the application of new ideas as one of them is the design of school-based management implementation (Rahayu, Sri Ulfiatin, Nurul Wiyono, Bambang B. Imron, ALi Wajdi, 2018). The process in 
Hidayatullah, M. F. (2021). QUALITY IMPROVEMENT DESIGN AT ISLAMIC SCHOOLS POST-COVID-19 PANDEMIC IN ELEMENTARY SCHOOL AND INTEGRATED EARLY CHILDHOOD EDUCATION OF SALEH CHILDREN, MALANG CITY. Jurnal Tatsqif, 19 (1), 81-97. https://doi.org/10.20414/itq.v19i1.3570

educational institutions is created through two forms of activities, namely academic and non-academic activities. These activities can be ascertained to have creativity and innovation to encourage the institution's vision, mission, goals, and ideals achievements.

Innovation of Integrated Early Childhood Education academic/nonacademic activities through program innovation with the term Anak Saleh Satsaguna Integrated Early Childhood Education (ECE). It means that six honor programs are beneficial for many people, including three academic programs (agents for developing learning innovations beyond centers and circle time (BCCT), multi-extra play, and parenting) and three nonacademic programs (internship centers and national comparative studies, inclusive schools, habitual Islamic culture). The term inclusion was obtained based on the following interview results:

If in Anak Saleh Integrated ECE, the curriculum is the hallmark of us, we are an inclusive school. One of the inclusive schools is also a reference school from the Department of Education and Culture for Anak Saleh Integrated ECE, an inclusive school. Furthermore, Alhamdulillah, the public response was enormous; thus, we limit accepting special children or children with special needs. Last year, we did not have to reject Alhamdulillah, but we limited it according to the existing quota; we adjusted it to the existing human resources and capabilities (Wawancara, 2020b).

In addition, the educational process at Anak Saleh Integrated ECE shows the seriousness of the learning process through the length of time for teaching and learning activities. During effective hours, educators enter, starting at 06.30 to 13.00 . However, in practice, they go home on average until 15.00, even for certain activities until 17.00 voluntarily (Arifin, 2011).

Meanwhile, the academic/non-academic innovation of Anak Saleh Elementary School (ES) is through academic and student programs. On the academics side, there is a term called Astha Karya program, which means eight skills possessed by students. In the future, these featured programs include Multilingual Program, Moving Home, Excursion Study, 
Hidayatullah, M. F. (2021). QUALITY IMPROVEMENT DESIGN AT ISLAMIC SCHOOLS POST-COVID-19 PANDEMIC IN ELEMENTARY SCHOOL AND INTEGRATED EARLY CHILDHOOD EDUCATION OF SALEH CHILDREN, MALANG CITY. Jurnal Tatsqif, 19 (1), 81-97. https://doi.org/10.20414/jtq.v19i1.3570

Outbound, Long day School, Al-Quran Learning and Memorization of Short Letters, Gardening, and Friday Cleaning and Swimming Class (Observasi, 2020b).

Furthermore, the innovation of student programs through the HomeBased System program based on rewards, motivation, and PCHB (Point Cutting Home-based) with several principles which include: first, the immense love the young, second, the young understand the older, then ready to be led and willing to lead, and the third is fastabiqul khoirot. The development of the Home-Based System program in the form of the formation of the MMT (Mosque Model Team) and the Green Force (GForce). The mosque model team is engaged in worship practice to shape personal, social, and intellectual character), while G-Force is engaged in worship practice to shape natural and national character.

\section{- Output (Academic/Non-Academic)}

Each educational institution strives to produce specific outputs according to the potential of each student. The effort to create the output is nothing but to show the totality of the institution in implementing education. An effective and efficient management system is needed that is not only based on logic and reason. There are several efforts made as called spiritual management, including (Umam, 2013): sincere lillahi ta'ala means accepting the students' condition gracefully to educate them, students' simplicity, management independence, strengthening the ties of brotherhood among human beings (hablumminannas) as the researchers called it, and trying with all his might, both teachers and students.

Thus, an output can be produced from the learning process for the collaboration of educators and students. Output is the result of the process carried out by students in the context of education. Anak Saleh Early Childhood Education (ECE) is one of the best Early Childhood Education in Malang City with many achievements. He has achieved various kinds of achievements such as First Winner in Provincial 
Hidayatullah, M. F. (2021). QUALITY IMPROVEMENT DESIGN AT ISLAMIC SCHOOLS POST-COVID-19 PANDEMIC IN ELEMENTARY SCHOOL AND INTEGRATED EARLY CHILDHOOD EDUCATION OF SALEH CHILDREN, MALANG CITY. Jurnal Tatsqif, 19 (1), 81-97. https://doi.org/10.20414/itq.v19i1.3570

Innovative Early Childhood Education (institutional achievement), First Winner in singing (student achievement), champion of work Early Childhood Education and National creative teachers, First Winner in Provincial teacher award (teacher achievement) and so on at local and national levels (Arifin, 2011).

All of these achievements are inseparable from the institution's quality, which is continuously improved. It is essential in managing educational institutions and improving quality. The two have a mutually influencing relationship. Anak Saleh Early Childhood Education success in achieving achievements and becoming a National Excellence Early Childhood Education cannot be separated from the high commitment of the school principal and educators. In addition, efforts to improve quality cannot be separated from the philosophy that characterizes the institution.

Furthermore, these five created varied and innovative programs that resulted in various achievements, some of which became the National Superior Early Childhood Education in Malang City from the Directorate General of Early Childhood Education (Arifin, 2011) through special programs including Internship Center and National Comparative Studies, Center for Learning Innovation Development Agent (beyond centers and circle time/BCCT), and have multi-extra play such as Angklung, Singing, Coloring and Painting, Contemporary and Traditional Dance, Swimming, Declamation and Poetry (Chovifah, 2008).

Meanwhile, Anak Saleh Elementary School (ES) received appreciation from the Malang City local government for the idea of nature-based educational institutions and mosques. In addition, Anak Saleh Elementary School (ES) in 2020 as an Inspirational Basic Education Institution at the Times Indonesia Malang Raya award (Anshori, 2020). In addition, the very diverse achievements of educators and students indicate the success of the process for the existence of input. 
- Logical Frame Work Design for Quality Improvement of Integrated Early Childhood Education (ECE) and Elementary Schools (ES) Saleh Children's, Malang City

The design for improving the quality of Anak Saleh Integrated ECE is illustrated based on the inputs, processes, and outputs as follows figure 1 .

Meanwhile, the design for improving the quality of Anak Saleh Elementary School (ES) starts with input, process, and output as shown in the following figure 2.

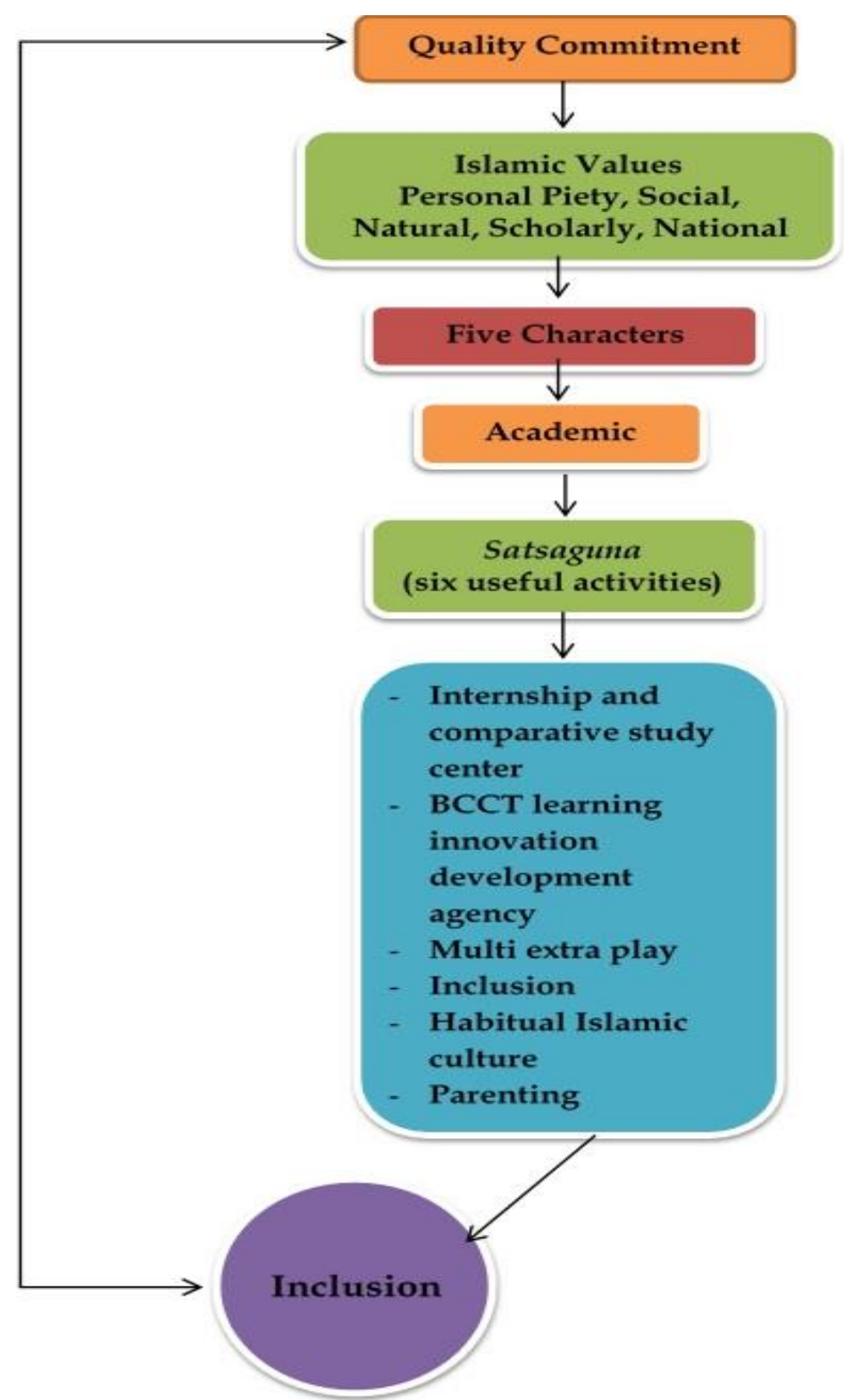

Figure 1. Logical Frame Work Design for Quality Improvement of Anak Saleh Integrated Early Childhood Education (ECE) 
Hidayatullah, M. F. (2021). QUALITY IMPROVEMENT DESIGN AT ISLAMIC SCHOOLS POST-COVID-19 PANDEMIC IN ELEMENTARY SCHOOL AND INTEGRATED EARLY CHILDHOOD EDUCATION OF SALEH CHILDREN, MALANG CITY. Jurnal Tatsqif, 19 (1), 81-97. https://doi.org/10.20414/itq.v19i1.3570

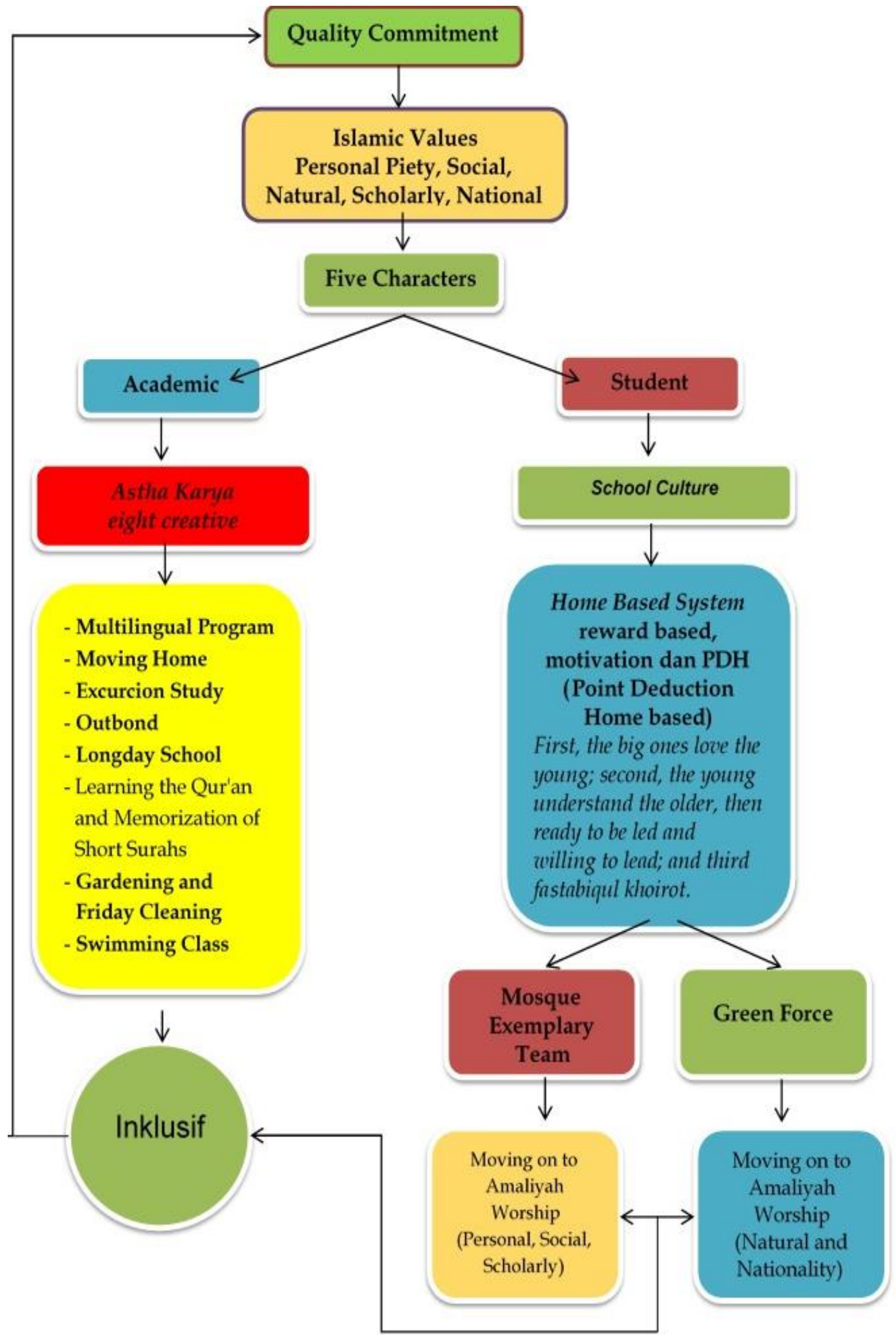

Figure 2. Quality improvement Logical Frame Work Design In Anak Saleh Elementary School (ES) 
Hidayatullah, M. F. (2021). QUALITY IMPROVEMENT DESIGN AT ISLAMIC SCHOOLS POST-COVID-19 PANDEMIC IN ELEMENTARY SCHOOL AND INTEGRATED EARLY CHILDHOOD EDUCATION OF SALEH CHILDREN, MALANG CITY. Jurnal Tatsqif, 19 (1), 81-97. https://doi.org/10.20414/jtq.v19i1.3570

\section{CONCLUSIONS}

Design quality improving the Anak Saleh Integrated Early Childhood Education (ECE) and Elementary School (ES) is based on the commitment to quality and the Five Characters of the Anak Saleh Foundation in Malang City as the philosophy of the institution, which in this case is included in the input category. Panca Characters are five characters used as the basis of institutions to be instilled in students, including personal piety, social, nationality, intellectuality, and naturalness. While in the process, there are differences. In Integrated Anak Saleh Early Childhood Education, there are six valuable activities for many people called Satsaguna. Meanwhile, the Anak Saleh Elementary School improves its quality through School Culture and Astha Karya activities, in which students must have these eight skills. Meanwhile, the output of Anak Saleh Integrated Early Childhood Education is an inclusive school, while the Anak Saleh Elementary School is an inclusive school.

\section{REFERENCES}

Administrator. (2020a). Latar Belakang Sekolah Dasar Anak Saleh. Sekolahanaksaleh.Sch.Id. https://sekolahanaksaleh.sch.id/sd/

Administrator. (2020b). Latar Belakang Yayasan Pendidikan Anak Saleh. Sekolahanaksaleh.Sch.Id. https://sekolahanaksaleh.sch.id/yayasan/\#sejarah

Administrator. (2020c). Sejarah PAUD Terpadu Anak Saleh. Sekolahanaksaleh.Sch.Id2. https://sekolahanaksaleh.sch.id/paud/\#profil Al Faqir, A. (2020). Kemendikbud Catat 646.200 Sekolah Tutup Akibat Virus Corona. Merdeka.Com. https://www.merdeka.com/uang/kemendikbud-catat-646200sekolah-tutup-akibat-virus-corona.html

Anshori, I. (2020). Inilah Peraih Anugerah TIMES Indonesia Wilayah Malang 
Hidayatullah, M. F. (2021). QUALITY IMPROVEMENT DESIGN AT ISLAMIC SCHOOLS POST-COVID-19 PANDEMIC IN ELEMENTARY SCHOOL AND INTEGRATED EARLY CHILDHOOD EDUCATION OF SALEH CHILDREN, MALANG CITY. Jurnal Tatsqif, 19 (1), 81-97. https://doi.org/10.20414/itq.v19i1.3570

Raya.

Timesindonesia.Co.Id2.

https://www.timesindonesia.co.id/read/news/246822/inilah-peraihanugerah-times-indonesia-wilayah-malang-raya

Arevalo, J. A., Mitchell, S. F., Rands, G., \& Starik, M. (2020). Guest Editors ' Introduction to the Special Issue: Sustainability in Management Education. Journal of Management Education, 44(6), 683-698. https://doi.org/10.1177/1052562920962832

Arifi, A. (2008). Anggaran Pendidikan dan Mutu Pendidikan (Respon Kebijakan Anggaran Pendidikan 20\% dari APBN bagi Upaya Peningkatan Mutu Pendidikan Madrasah). Jurnal Pendidikan Agama Islam, $V(1), 111-127$.

Arifin, I. (2011). Strategi Kepala Sekolah Dalam Mengimplementasikan PAUD Unggulan Nasional. Jurnal Pendidikan Dan Pembelajaran Universitas Negeri Malang, 18(1), 29-35.

Aziz, A. Z. (2015). MANAJEMEN BERBASIS SEKOLAH: ALTERNATIF PENINGKATAN MUTU PENDIDIKAN MADRASAH. El-Tarbawi, VIII(1), 69-92.

Bakri, M. (2013). Metodologi Penelitian Kualitatif: Tinjauan Teoritis dan Praktis. Visipress Media.

Biadacz, R. (2021). Quality cost management in the SMEs of Poland. The TQM Journa, 33(7), 1-38. https://doi.org/10.1108/TQM-09-2019-0223

Chovifah, S. (2008). Penerapan metode BCCT (Beyond Centers and Circle Time) di PAUD Unggulan Nasional Anak Saleh. Universitas Islam Negeri Maulana Malik Ibrahim Malang.

Engkoswara. (2012). Administrasi Pendidikan. Alfabeta.

Hermawan, I., Ruswandi, U., \& Erihadiana, M. (2020). The Concept of Management of Learning Mkwu Pai Based on Multicultural Components. Ta Dib: Jurnal Pendidikan Islam, 9(1), 63-76. https://doi.org/10.29313/tjpi.v9i1.6233

Islam, A. (2013). Evaluasi Dampak Peningkatan Mutu Pendidikan Dasar 
Hidayatullah, M. F. (2021). QUALITY IMPROVEMENT DESIGN AT ISLAMIC SCHOOLS POST-COVID-19 PANDEMIC IN ELEMENTARY SCHOOL AND INTEGRATED EARLY CHILDHOOD EDUCATION OF SALEH CHILDREN, MALANG CITY. Jurnal Tatsqif, 19 (1), 81-97. https://doi.org/10.20414/jtq.v19i1.3570

(Studi Tentang Program Desentralized Basic Education 2 (DBE2) Di Kabupaten Nganjuk). Jurnal Administrasi Publik Mahasiswa Universitas Brawijaya, 1(6), 1096-1105.

Kemendikbud. (2018). Jumlah Sekolah Menurut Jenjang Tahun Ajaran $2017 / 2018$. Databoks.Katadat.Co.Id. https://databoks.katadata.co.id/datapublish/2019/06/23/berapajumlah-sekolah-di-indonesia\#: :text=Jumlah tersebut\%2C berdasarkan data pokok,negeri dan 138.277 sekolah swasta\%2C .

Miles, M.B, Huberman, A.M, dan Saldana, J. (2014). Qualitative Data Analysis, A Methods Sourcebook, Edition 3. USA: Sage Publications. Terjemahan Tjetjep Rohindi Rohidi. UI-Press.

Mulyadi. (2007). Manajemen Berbasis Sekolah. Bumi Aksara.

Mulyasa, E. (2014). Manajemen Berbasis Sekolah: Konsep, Strategi, dan Implementasi. Remaja Rosdakarya.

Observasi. (2020a). 11 Oktober.

Observasi. (2020b). 25 Februari.

Rahayu, Sri Ulfiatin, Nurul Wiyono, Bambang B. Imron, ALi Wajdi, Muh. B. N. (2018). The Professional Competency Teachers Mediate the Influence of Teacher Innovation and Emotional Intelligence on School Security. Journal of Social Studies Education Research Sosyal, 9(2), 210-227.

Rahmawati, I. D. (2012). MANAJEMEN SUMBER DAYA MANUSIA (SDM) DALAM PENINGKATAN KUALITAS SEKOLAH (Studi Empirik Madrasah Ibtidayah (MI) Muhammadiyah Program Khusus Kartasura Tahun Pelajaran 2011/2012 ) NASKAH. Universitas Muhammadiyah Surakarta.

Rizescu, Alexandru; Tileag, C. (2017). THE EFFECTS OF GLOBALIZATION ON THE TRANSFORMATION OF ORGANIZATIONAL MANAGEMENT. Journal of Defense Resources Management, 8(1), 135-140.

Rochim, A. (2020). Banyak Lembaga Pendidikan Gulung Tikar, Pemerintah Diminta Turun Tangan. Edukasi.Sindonews.Com. https://edukasi.sindonews.com/read/90540/144/banyak-lembaga- 
pendidikan-gulung-tikar-pemerintah-diminta-turun-tangan1593871642

Rohiat. (2010). Manajemen Sekolah Teori Dasar dan Praktek. Refika Aditama.

Rusmini. (2015). Peningkatan mutu lembaga pendidikan tinggi melalui pengembangan sumber daya manusia. Al FIkroh, 11-24.

Santoso, G. (2005). Metodologi Penelitian Kualitatif dan Kuantitatif. Prestasi Pustaka.

Seftiawan, D. (2019). PPDB Sistem Zonasi Kendurkan Semangat Belajar Siswa. Pikiranrakyat.Com. https://www.pikiran-rakyat.com/pendidikan/pr01313780/ppdb-sistem-zonasi-kendurkan-semangat-belajar-siswa

Sugiono. (2016). Metode Penelitian Pendidikan (Pendekatan Kuantitatif, Kualitatif dan $R \& D$ ). Alfabeta.

Supriyatno, H. (2020). Mengantisipasi Ancaman “Gulung Tikar" Sekolah Swasta. Harianbhirawa.Co.Id. https://www.harianbhirawa.co.id/mengantisipasi-ancaman-gulungtikar-sekolah-swasta/

Umam, K. (2013). DEVELOPING MANAGEMENT STANDARDS BASED ON ISLAMIC VALUES : CASE STUDY OF DARUSSALAM GONTOR MODERN. Qudus International Journal of Islamic Studies, 1(2), 145-162.

Wawancara. (2020a). Kepala Sekolah 14 Februari.

Wawancara. (2020b). Waka Kurikulum dan Pembelajaran 18 Februari. 